\title{
Stereoselective Hydroazidation of Amino Enones: Synthesis of the Ritonavir/Lopinavir Core
}

\author{
Ilaria Adamo, Fabio Benedetti, ${ }^{*}$ Federico Berti, and Pietro \\ Campaner
}

Department of Chemical Sciences, University of Trieste, via Giorgieri 1, I-34127

Trieste, Italy

benedett@units.it

Tert-butyl (R,E)-3-oxo-1,6-diphenylhex-4-en-2-ylcarbamate (7)

The enone was obtained as described in the Scheme (see ref. 16):

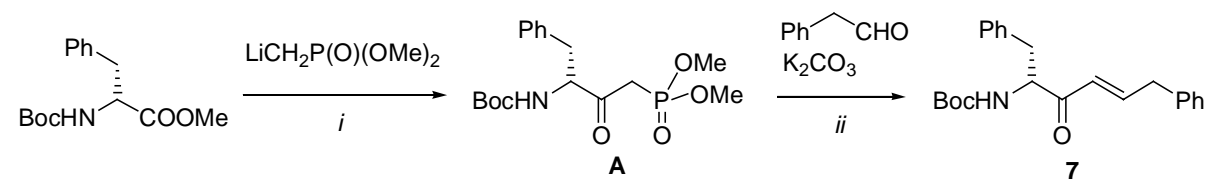

i. A $2.5 \mathrm{M}$ solution of $\mathrm{n}$-BuLi in $\mathrm{n}$-hexane $(12 \mathrm{ml}, 30 \mathrm{mmol})$ is added dropwise under an argon atmosphere, at $-78{ }^{\circ} \mathrm{C}$, with stirring, to a solution of methyldimethylphosphonate $(3.45 \mathrm{~g}, 30 \mathrm{mmol})$ in $30 \mathrm{ml}$ THF. The solution is stirred at $-78^{\circ} \mathrm{C}$ for $15 \mathrm{~min}$ and N-Boc-D-phenylalanine methylester $(1.42 \mathrm{~g}, 5.1 \mathrm{mmol})$ in $5 \mathrm{ml}$ THF is added dropwise. The reaction mixture is stirred for $2 \mathrm{~h}$ at $-78{ }^{\circ} \mathrm{C}$, then for $1 \mathrm{~h}$ at $-30^{\circ}$, and poured into $60 \mathrm{ml}$ of $20 \%$ aqueous citric acid. The mixture is extracted with ethyl acetate $(2 \times 30 \mathrm{ml})$ and the combined organic phases are washed with sat. aqueous $\mathrm{NaHCO}_{3}$ and brine and dried over an. sodium sulfate. Evaporation of the solvent under reduced pressure and flash chromatography of the residue $(5 \% \mathrm{MeOH}$ in $\mathrm{AcOEt})$ gave pure phosphonate $\mathbf{A}$ (1.7 g, 89\%). M.p. $65-66{ }^{\circ} \mathrm{C}$ (from isoprop ylether); $[\alpha]_{\mathrm{D}}{ }^{25}=+52^{\circ}(\mathrm{c}=0.4, \mathrm{MeOH})$; IR (nujol): $3267 ; 1713 ; 1600 ; 1244 \mathrm{~cm}^{-1} ;{ }^{1} \mathrm{H}-\mathrm{NMR}\left(\mathrm{CDCl}_{3}\right) \delta: 1.39(\mathrm{~s}, 9 \mathrm{H}) ;[2.93(\mathrm{dd}, 1 \mathrm{H}, \mathrm{J}=8.3,14.2 \mathrm{~Hz}) \mathrm{e}$ $3.18(\mathrm{dd}, 1 \mathrm{H}, \mathrm{J}=6.1,14.2 \mathrm{~Hz})] ;[3.10(\mathrm{dd}, 1 \mathrm{H}, \mathrm{J}=14.2,22.0 \mathrm{~Hz})$ e $3.26(\mathrm{dd}, 1 \mathrm{H}, \mathrm{J}=14.2,22.0 \mathrm{~Hz})]$; $3.75\left(\mathrm{~d}, 3 \mathrm{H}, \mathrm{J}_{\mathrm{H}-\mathrm{P}}=11.5 \mathrm{~Hz}\right) ; 3.77\left(\mathrm{~d}, 3 \mathrm{H}, \mathrm{J}_{\mathrm{H}-\mathrm{P}}=11.5 \mathrm{~Hz}\right) ; 4.55(\mathrm{~m}, 1 \mathrm{H}) ; 5.43(\mathrm{~d}, 1 \mathrm{H}, \mathrm{NH}, \mathrm{J}=7.8 \mathrm{~Hz})$; $7.19(\mathrm{~d}, 2 \mathrm{H}) ; 7.24(\mathrm{~d}, 2 \mathrm{H}) ; 7.30(\mathrm{t}, 1 \mathrm{H}) ;{ }^{13} \mathrm{C}-\mathrm{NMR}\left(\mathrm{CDCl}_{3}\right) \delta: 28.2,36.8,38.3\left(\mathrm{~d}, \mathrm{CH}_{2}-\mathrm{P}\right.$; $\mathrm{J}=130 \mathrm{~Hz}), 53.1,61.1,80.1,126.8,128.5,129.2,136.4,155.3,201.0$ (d, C=O; J=5.5Hz); ES-MS $(\mathrm{m} / \mathrm{z}): 372[\mathrm{MH}]^{+}, 316\left[\mathrm{MH}-\mathrm{C}_{4} \mathrm{H}_{8}\right]^{+}, 272\left[\mathrm{MH}-\mathrm{C}_{5} \mathrm{H}_{8} \mathrm{O}_{2}\right]^{+}$.

ii. Oven dried $\mathrm{K}_{2} \mathrm{CO}_{3}(553 \mathrm{mg}, 4.0 \mathrm{mmol})$ was added in small portions, over $15 \mathrm{~min}$, to a stirred solution of phosphonate A (1.49 g, $4.0 \mathrm{mmol})$ and phenylacetaldehyde $(480 \mathrm{mg}, 4.0 \mathrm{mmol})$ in absolute ethanol $(40 \mathrm{~mL})$. After $25 \mathrm{~min}$ the reaction mixture was filtered and the solution was neutralized with glacial acetic acid. The solvent was removed under reduced pressure and the residue was partitioned between ethyl acetate and saturated aqueous $\mathrm{NaHCO}_{3}$. The aqueous phase was extracted with ethyl acetate and the combined organic phases were washed with brine and dried over sodium sulphate. The solvent was rotary evaporated and the residue was purified by flash chromatography with diethyl ether and petroleum ether (1:1) as eluant giving 7 (730 mg, 50\%); white crystals: $\mathrm{mp} 79-80^{\circ} \mathrm{C}$, from diisopropyl ether/petroleum ether; $[\alpha]_{\mathrm{D}}{ }^{25}=+6$ (c 1.0); IR (nujol) 3360, 1690, $1623 \mathrm{~cm}^{-1} ;{ }^{1} \mathrm{H}$ NMR $\left(\mathrm{CDCl}_{3}\right) \delta 1.40(\mathrm{~s}, 9 \mathrm{H}), 2.97(\mathrm{dd}, 1 \mathrm{H}, J=5.9,13.7 \mathrm{~Hz}), 3.06(\mathrm{dd}$, 
$1 \mathrm{H}, J=6.8,13.7 \mathrm{~Hz}), 3.48(\mathrm{~d}, 2 \mathrm{H}, J=6.6 \mathrm{~Hz}), 4.79(\mathrm{~m}, 1 \mathrm{H}), 5.26(\mathrm{~d}, \mathrm{NH}), 6.08(\mathrm{~d}, 1 \mathrm{H}, J=15.6 \mathrm{~Hz})$, $7.03(\mathrm{dt}, 1 \mathrm{H}, J=6.6,15.6 \mathrm{~Hz}), 7.10-7.32(\mathrm{~m}, 10 \mathrm{H}) ;{ }^{13} \mathrm{C} \mathrm{NMR}\left(\mathrm{CDCl}_{3}\right) \delta 28.3,38.5,38.8,58.4,79.7$, $126.79,126.85,128.0,128.4,128.7,128.8,129.5,136.1,137.2,147.7,155.1,197.4 ; \mathrm{MS}, \mathrm{m} / z 366$ $[\mathrm{MH}]^{+}, 310\left[\mathrm{MH}-\mathrm{C}_{4} \mathrm{H}_{8}\right]^{+}, 266\left[\mathrm{MH}-\mathrm{C}_{5} \mathrm{H}_{8} \mathrm{O}_{2}\right]^{+}$; Anal. Calcd. for $\mathrm{C}_{23} \mathrm{H}_{27} \mathrm{NO}_{3}: \mathrm{C}, 75.6 ; \mathrm{H}, 7.44 ; \mathrm{N}$, 3.83. Found: C, 75.8; H, 7.54; N, 3.86.

\section{Tert-Butyl (1S,4S)-4-Azido-1-benzyl-2-oxy-5-phenylpentyl-carbamate (4a)}

A solution of $\mathrm{TMSN}_{3}(1.8 \mathrm{ml}, 13.7 \mathrm{mmol})$, and acetic acid $(0.85 \mathrm{ml}, 13.7 \mathrm{mmol})$ in dichloromethane $(50 \mathrm{ml})$ was stirred under argon at room temperature. After $20 \mathrm{~min}$ a solution of enone 3 (1.0 g, $2.7 \mathrm{mmol})$ and $L$-proline methyl ester $(0.07 \mathrm{~g}, 0.54 \mathrm{mmol})$ in dichloromethane (25 $\mathrm{ml}$ ) was added. The reaction was followed by TLC (ether-PE 1:1). When the conversion was complete the crude mixture was eluted with dichloromethane through a short silica gel column. The solvent was evaporated under reduced pressure and the major diastereoisomer $\mathbf{4 a}$ was isolated by crystallization from isopropyl ether $(0.78 \mathrm{~g}, 1.9 \mathrm{mmol}, 70 \%)$ : m.p. $=84-85^{\circ} \mathrm{C} ;[\alpha]_{\mathrm{D}}{ }^{25}=-41(\mathrm{MeOH}$, $\mathrm{c}=0.2)$; IR (nujol): 3350, 2110, $1715 \mathrm{~cm}^{-1} ;{ }^{1} \mathrm{H}-\mathrm{NMR}\left(\mathrm{CDCl}_{3}\right) \delta 1.40(\mathrm{~s}, 9 \mathrm{H}) ; 2.40$ (dd, $1 \mathrm{H}, \mathrm{J}=4$, $17 \mathrm{~Hz}) ; 2.60(\mathrm{dd}, 1 \mathrm{H}, \mathrm{J}=8,17 \mathrm{~Hz}) ; 2.75(\mathrm{~d}, 2 \mathrm{H}, 6 \mathrm{~Hz}) ; 2.95(\mathrm{~m}, 2 \mathrm{H}) ; 4.05(\mathrm{~m}, 1 \mathrm{H}) ; 4.45(\mathrm{q}, 1 \mathrm{H}, 7 \mathrm{~Hz})$; $5.04(\mathrm{~d}, 1 \mathrm{H}, 7 \mathrm{~Hz}) ; 7.08-7.31(\mathrm{~m}, 10 \mathrm{H}) ;{ }^{13} \mathrm{C}-\mathrm{NMR}\left(\mathrm{CDCl}_{3}\right) \delta 28.3,37.5,40.7,44.5,59.1,60.6,80.3$, 127.0, 136.0, 137.0, 155.3, 206.5, 207.0; ES-MS (m/z): $409[\mathrm{MH}]^{+}, 353\left[\mathrm{MH}-\mathrm{C}_{4} \mathrm{H}_{8}\right]^{+}$.

\section{Tert-Butyl (1R,4R)-4-Azido-1-benzyl-2-oxy-5-phenylpentyl-carbamate (8a)}

With the same procedure described for the synthesis of $\mathbf{4 a}$, the enone 7 (1.0 g, $2.7 \mathrm{mmol})$ gave a 4:1 mixture of azides $\mathbf{8 a}$ and $\mathbf{8 b}$. Pure 8a was obtained by crystallization from isopropyl ether (0.66 g, $1.6 \mathrm{mmol}, 60 \%)$ : m.p. $=85-86^{\circ} \mathrm{C} ;[\alpha]_{\mathrm{D}}{ }^{25}=+39(\mathrm{MeOH}, \mathrm{c}=0.2)$.

\section{Tert-Butyl (1S,2S,4S)-4-Azido-1-benzyl-2-hydroxy-5-phenylpentyl-carbamate (10)}

A $1 \mathrm{M}$ solution of L-selectride in THF $(5.7 \mathrm{ml}, 5.7 \mathrm{mmol})$ was added dropwise, under argon, at $78^{\circ} \mathrm{C}$ to the keto-azide $4 \mathbf{a}(0.78 \mathrm{~g}, 1.9 \mathrm{mmol})$ in freshly distilled $\mathrm{MeOH}(150 \mathrm{ml})$ and the resulting solution was stirred for $1 \mathrm{~h}$ at $-78^{\circ} \mathrm{C}$, whereupon TLC monitoring (AcOEt-PE 3:7) showed that the reaction was complete. The mixture was acidified to $\mathrm{pH} 5$ with $1 \mathrm{M} \mathrm{HCl}$ and the solvent was evaporated under reduced pressure. The residue was partitioned between AcOEt $(70 \mathrm{ml})$ and saturated $\mathrm{NaHCO}_{3}(70 \mathrm{ml})$ and the aqueous layer was extracted with AcOEt $(3 \times 40 \mathrm{ml})$. The combined organic phases were washed with saturated aqueous $\mathrm{NaCl}$ and dried over $\mathrm{Na}_{2} \mathrm{SO}_{4}$. The crude product was purified by flash cromatography (eluting solvent AcOEt-light petroleum 2:8). 
${ }^{1} \mathrm{H}-\mathrm{NMR}\left(\mathrm{CDCl}_{3}\right)$ of the mixture of diastereoisomers $4 \mathrm{a}$ and $4 \mathrm{~b}$

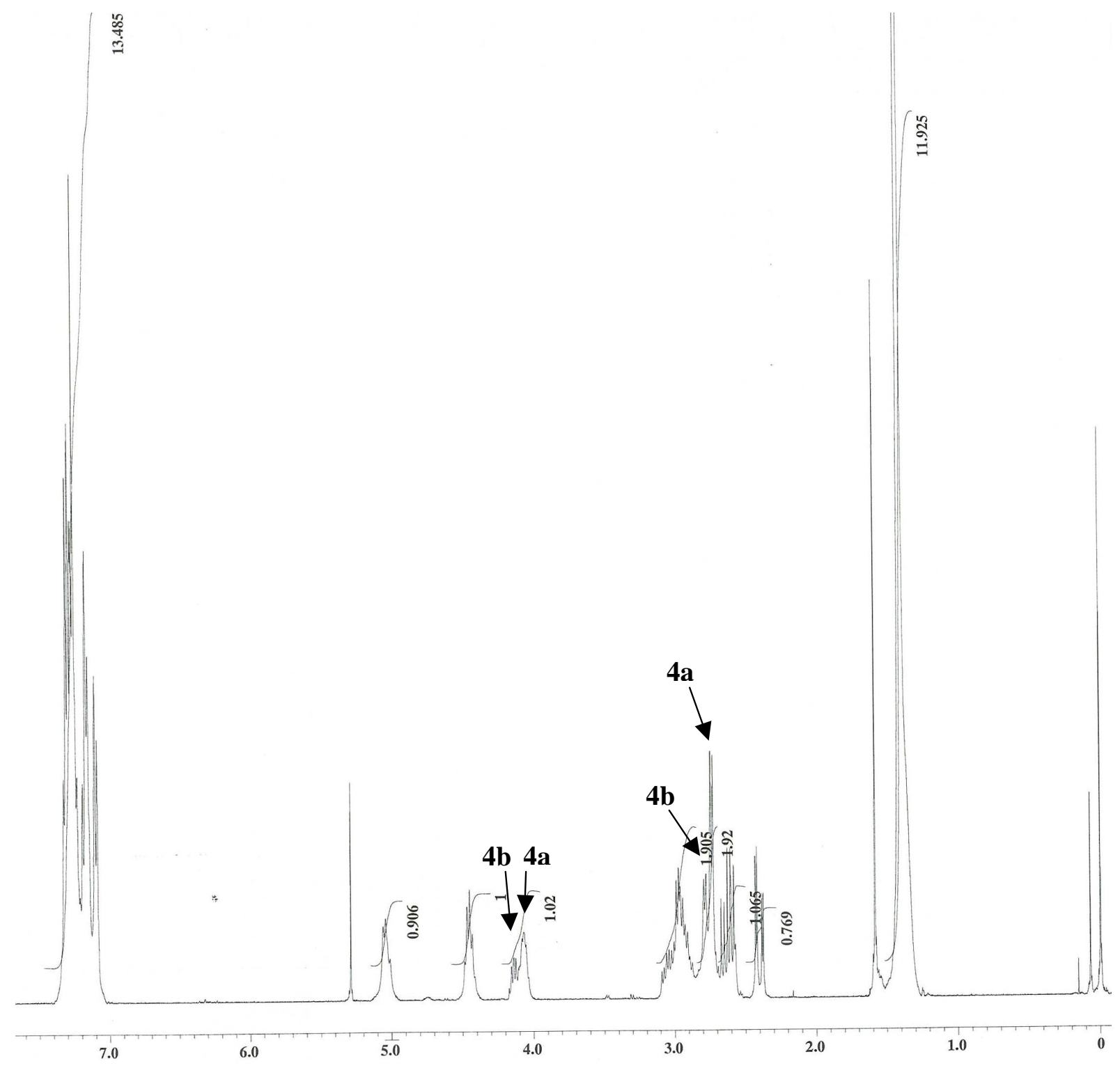




\section{${ }^{1}$ H-NMR $\left(\mathrm{CDCl}_{3}\right)$}
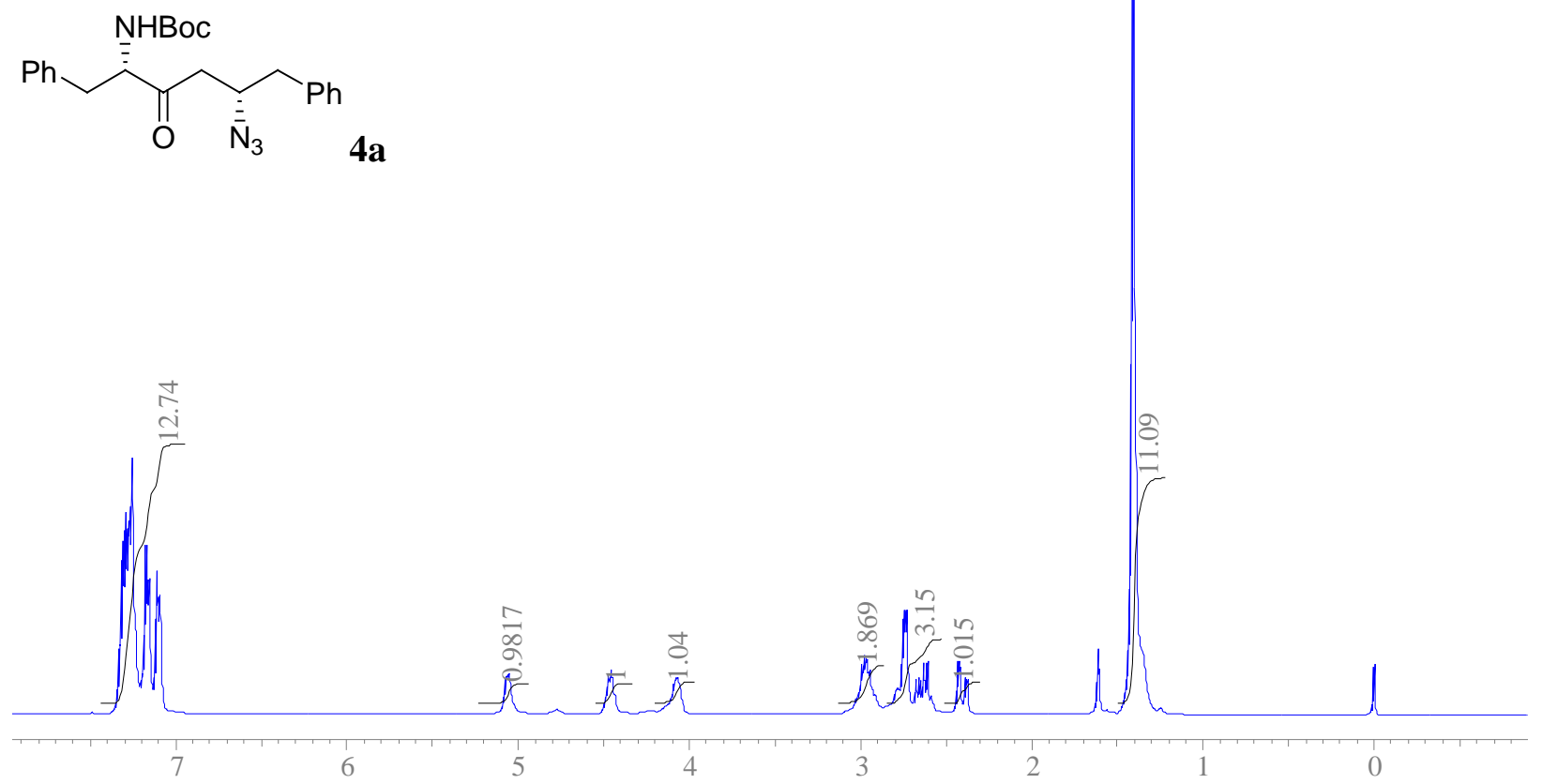

\section{${ }^{13} \mathrm{C}-\mathrm{NMR}\left(\mathrm{CDCl}_{3}\right)$}

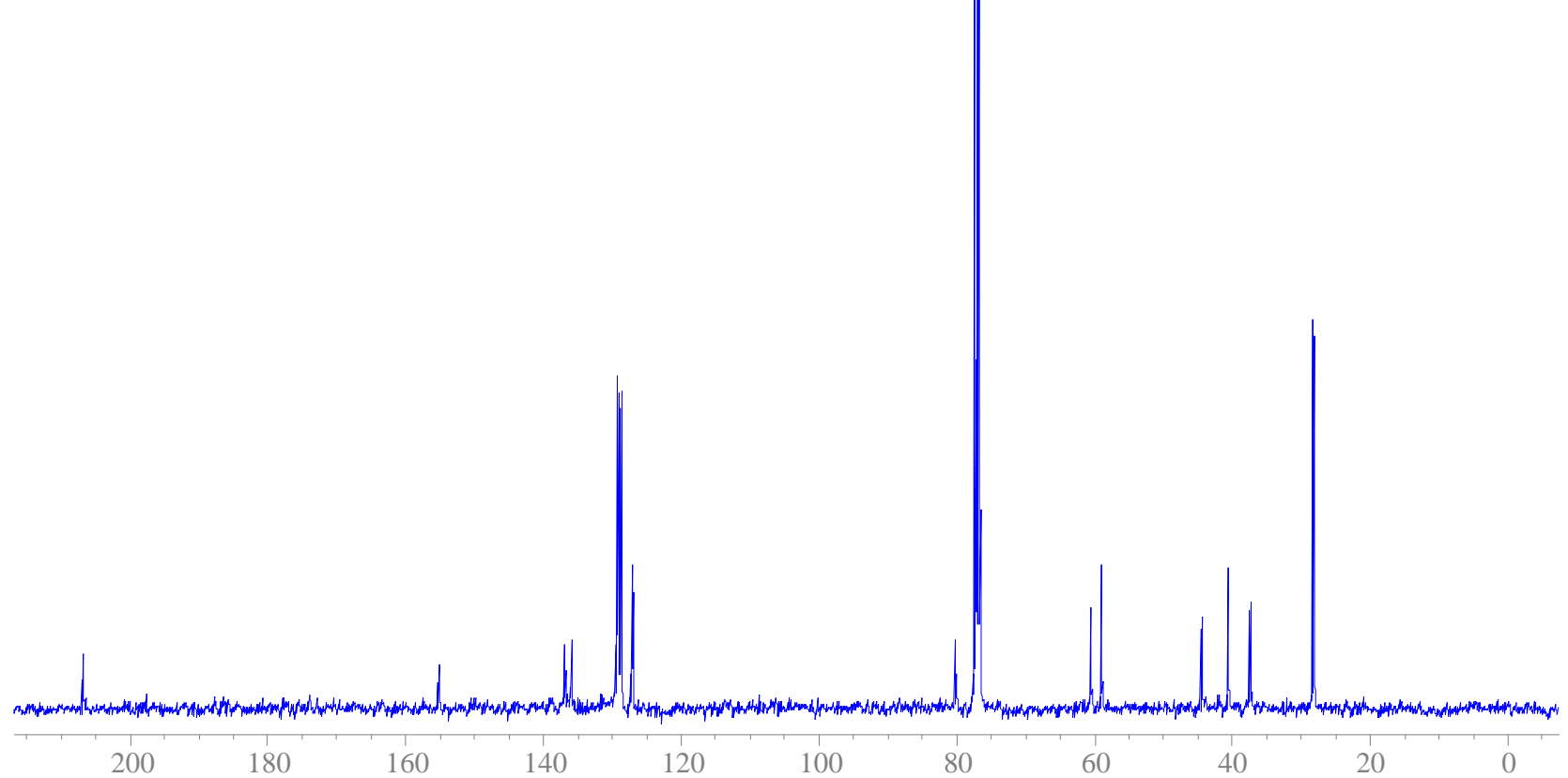




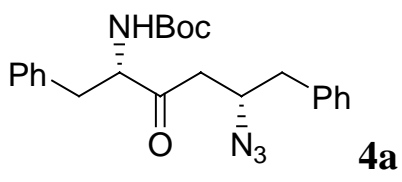

\section{IR (nujol)}

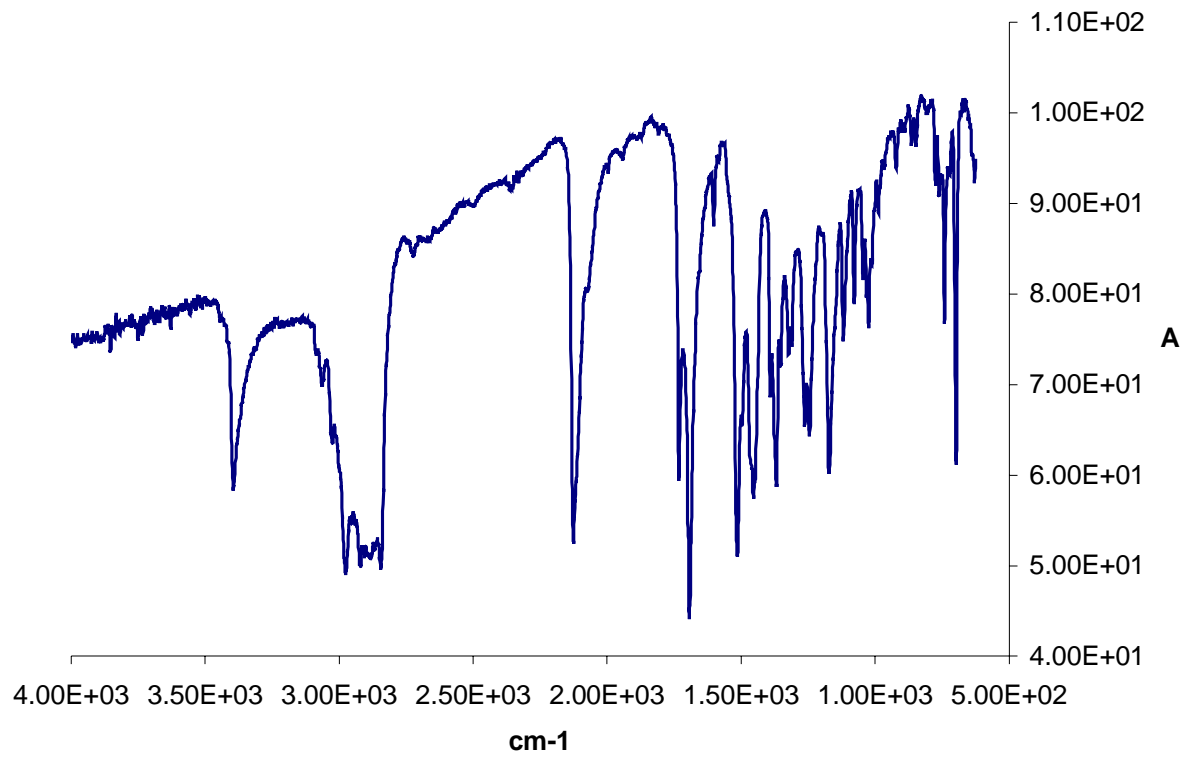

$\mathrm{UV}$-visible $4.7 \times 10^{-5} \mathrm{M}$ in $\mathrm{MeOH}$

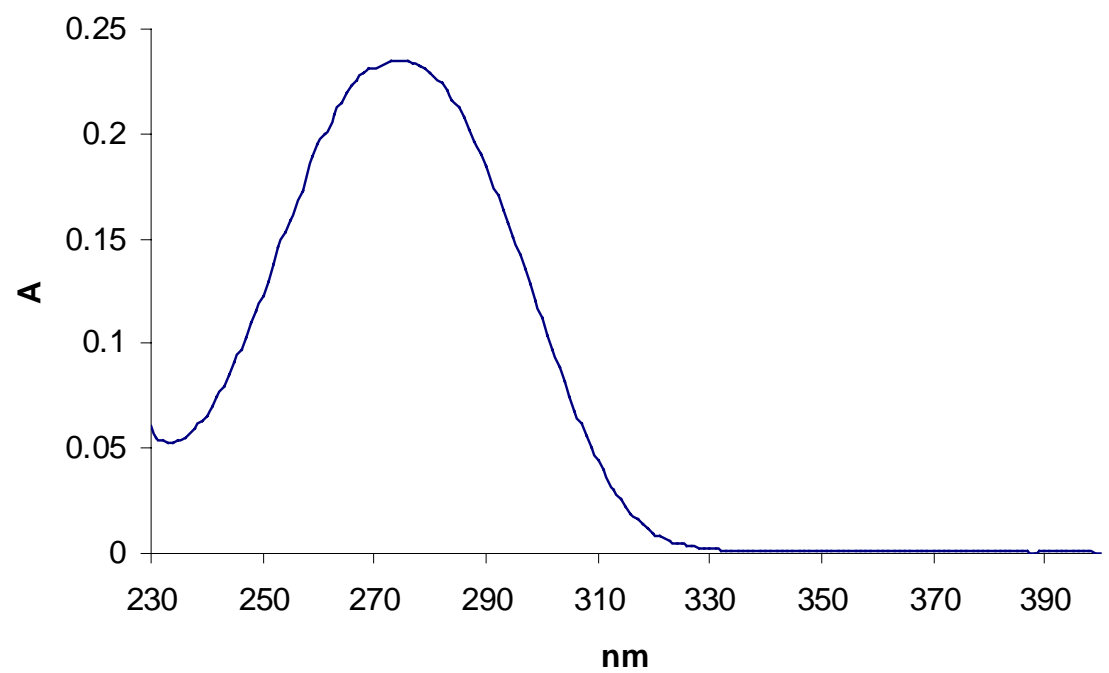




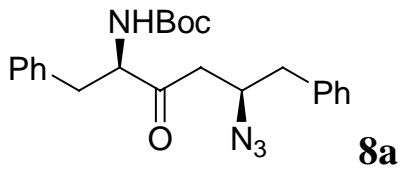

${ }^{1} \mathrm{H}-\mathrm{NMR}(400 \mathrm{MHz})$ in $\mathrm{CDCl}_{3}$

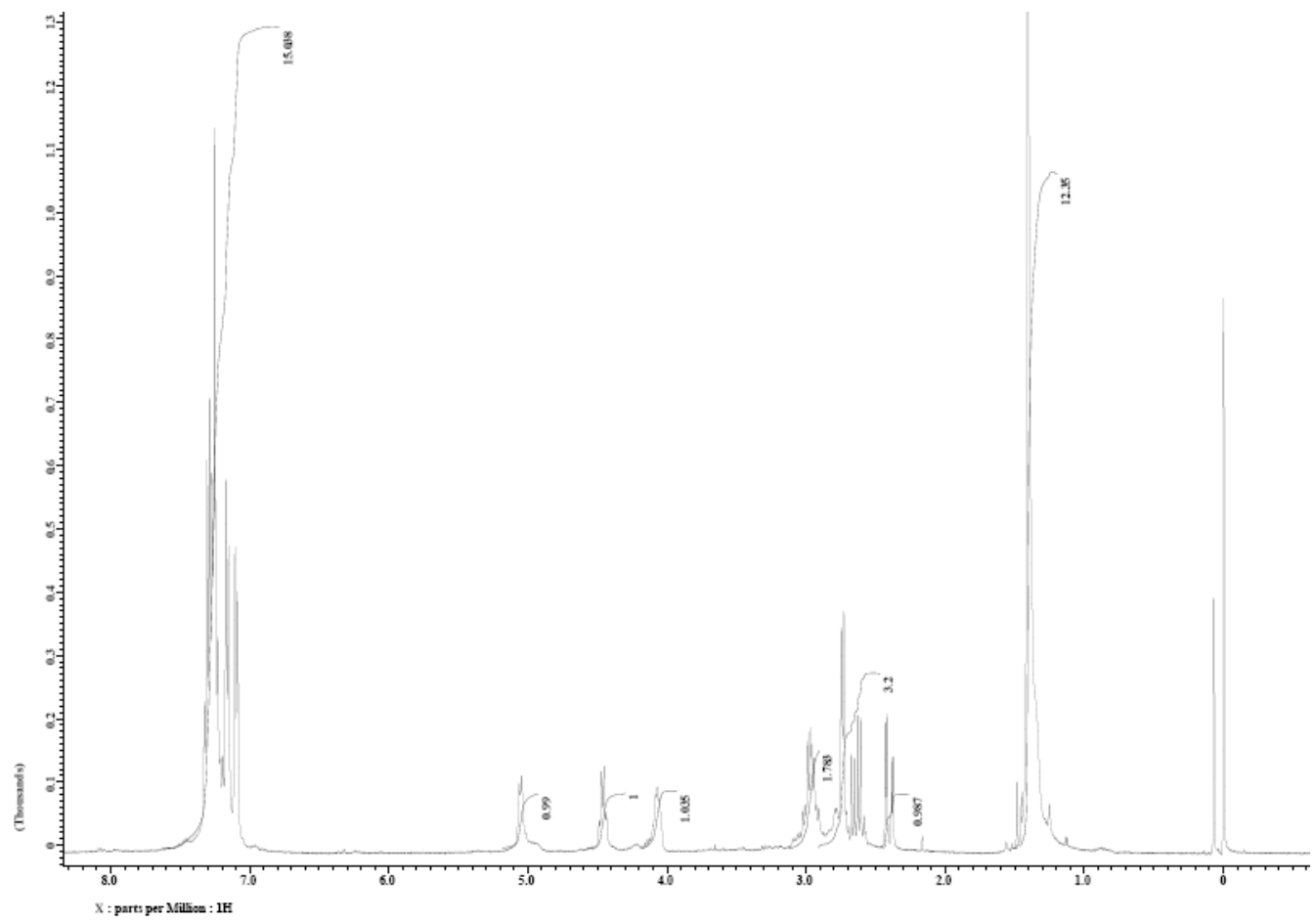


chiral HPLC analysis of the enantiomers $4 a$ and $8 a$

OD column, eluent $i$-PrOH-hexane 1:9, flow $1 \mathrm{ml} / \mathrm{min}$

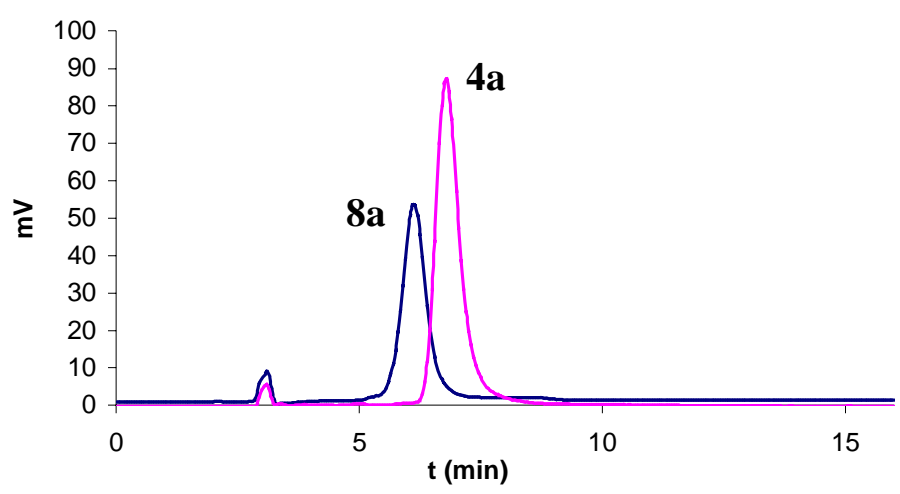

